\title{
Analisis Pencapaian Strategi Menggunakan Balanced Scorecard
}

\author{
Siti Hajar Nurlaila ${ }^{1}$
}

\author{
Menik Meltra Putri
}

Mahasiswa Fakultas Ekonomi dan Bisnis, Jurusan Manajemen Universitas Narotama

\begin{abstract}
The purpose of this research is measurement strategy achievement of public education office of surabaya city using Balanced Scorecard as a measurement tool based on financial perspective, internal business process perspective, customer perspective, and learning and growth perspective. The research approach used is descriptive qualitative by using the method of observation and interview and then analyzed by giving an overview of the performance of the strategy undertaken and explain systematically. The stages of the analysis include weighting performance to measure the number of indexes, which consists of Major Performance Indicator Achievement Index (IKU), Strategic Target Value (NSS), Performance Perspective Value (NKP), Unit Performance Value $(N K U)$.
\end{abstract}

Keywords: Strategy achievement; Balanced scorecard; Performance

\begin{abstract}
ABSTRAK
Tujuan dari penelitian ini adalah mengukur pencapaian startegi Dinas Pendidikan Kota Surabaya menggunakan Balanced Scorecard sebagai alat ukur berbasis strategis, meliputi financial perspectice, internal proses business perspective, customer perspective, serta learning dan growth perspectif. Pendekatan penelitian yang digunakan adalah pendekatan deskriptif kualitatif dengan menggunakan metode studi observasi dan wawancara. Tahapan analisis yang dilakukan meliputi pembobotan kinerja untuk menilai besaran angka/indeks,yang terdiri dari; Indeks Capaian Indikator Kinerja Utama (IKU), Nilai Sasaran Strategis (NSS), Nilai Kinerja Perspektif (NKP), Nilai Kinerja Unit (NKU).
\end{abstract}

Kata kunci: Pencapaian strategi; Balanced Scorecard; Kinerja

\section{PENDAHULUAN}

\subsection{Latar Belakang}

Pendidikan merupakan kegiatan yang berkaitan langsung dengan pembangunan manusia namun bila berbicara mengenai masalah pendidikan akan semakin banyak masalah yang muncul dikarenakan pendidikan sangatlah komplek. Dinas Pendidikan Kota Surabaya telah mencanangkan visi dan misi serta beberapa program untuk mengurai permasalahan serta mengatasi permasalahan - permasalahan tersebut. Demi mencapai tujuan peningkatan mutu pendidikan di kota surabaya serta mengurai permasalahan-permasalahan yang ada di dunia 
pendidikan di Kota Surabaya maka Dinas Pendidikan Kota Surabaya membuat sebuah visi yaitu "Menjadikan Surabaya Sebagai Barometer Pendidikan Nasional".

Selain itu, Dinas Pendidikan Kota Surabaya selama ini belum menggunakan analisis balanced scorecard dalam pengukuran kinerja terkait penerapan strategi yang telah berjalan, hanya menggunakan analisis serapan atas anggaran. Padahal, masyarakat Kota Surabaya semakin kritis terhadap nilai layanan yang mereka peroleh dari pemerintah.

Oleh karena itu, untuk dapat melihat pencapaian kinerja menyeluruh, Dinas Pendidikan Kota Surabaya dapat menerapkan Balanced Scorecard sebagai alat ukur berbasis strategis. Adapun balanced scorecard meliputi financial perpectice, internal proses business perspective, customer perspective, dan learning dan growth.

\subsection{Rumusan Masalah}

Apakah penerapan strategi Balanced Scorecard dapat menjadi solusi bagi Dinas Pendidikan Kota Surabaya dalam meningkatkan mutu pendidikan di Kota Surabaya?

\subsection{Tujuan Penelitian}

Tujuan dari penelitian ini adalah mengukur pencapaian startegi Dinas Pendidikan Kota Surabaya menggunakan Balanced Scorecard sebagai alat ukur berbasis strategis, meliputi financial perspectice, internal proses business perspective, customer perspective, serta learning dan growth perspectif.

\section{TINJAUAN PUSTAKA}

Balanced Scorecard merupakan suatu sistem manajemen strategi yang menjabarkan visi dan strategi suatu perusahaan ke dalam tujuan operasional dan tolak ukur. Tujuan dan tolak ukur dikembangkan untuk setiap 4 (empat) perspektif yaitu: perspektif keuangan, perspektif pelanggan, perspektif proses usaha dan perspektif pembelajaran dan pertumbuhan. Balanced scorecard menurut Kaplan dan Norton (2001:117) ukuran kinerja keuangan saja tidaklah cukup untuk menilai kinerja perusahaan yang diharapkan berhasil di masa depan tetapi juga harus memperhatikan empat aspek ukuran kinerja yaitu: perspektif belajar dan tumbuh 
(learning and growth perspective), perspektif proses internal/bisnis (customer perspective), dan perspektif keuangan (financial perspective).

Manfaat balanced scorecard bagi perusahaan menurut (Robert S. Kaplan, 2001) adalah sebagai berikut: (1) balanced scorecard mengintegrasikan strategi dan visi perusahaan untuk mencapai tujuan jangka pendek dan jangka panjang; (2) balanced scorecard memungkinkan manajer untuk melihat bisnis dalam perspektif keuangan dan non keuangan (pelanggan, proses bisnis internal, dan belajar dan bertumbuh), dan (3) balanced scorecard memungkinkan manajer menilai apa yang telah mereka investasikan dalam pengembangan sumber daya manusia, sistem dan prosedur demi perbaikan kinerja perusahaan di masa mendatang.

Kaplan dan Norton (Robert S. Kaplan, 2001) menggunakan empat standar perspektif balanced scorecard yaitu:

(1) perspektif keuangan, yaitu balanced scorecard dibangun dari studi pengukuran kinerja di sektor bisnis, sehingga yang dimaksud dengan perspektif keuangan di sini adalah terkait dengan financial sustainability. Perspektif ini digunakan oleh stakeholder dalam rangka melakukan penilaian kinerja organisasi. Apabila dinarasikan akan berbunyi "organisasi harus memenuhi sebagaimana harapan stakeholder agar dinilai berhasil oleh stakeholder;

(2) perspektif pelanggan, yaitu perspektif yang berorientasi pada pelanggan karena merekalah pemakai produk/ jasa yang dihasilkan organisasi. Dengan kata lain, organisasi harus memperhatikan apa yang diinginkan oleh pelanggan;

(3) perpektif proses bisnis internal, yaitu serangkaian aktivitas yang ada dalam organisasi untuk menciptakan produk/jasa dalam rangka memenuhi harapan pelanggan. Perspektif ini menjelaskan proses bisnis yang dikelola untuk memberikan layanan dan nilai-nilai kepada stakeholder dan customer, dan

(4) perspektif pembelajaran dan pertumbuhan, yaitu perspektif yang menggambarkan kemampuan organisasi untuk melakukan perbaikan dan perubahan dengan memanfaatkan sumber daya internal organisasi. Kesinambungan suatu organisasi dalam jangka panjang sangat tergantung pada perspektif ini.

\section{METODE PENELITIAN}


Pendekatan penelitian yang digunakan adalah deskriptif kualitatif dengan menggunakan metode observasi dan wawancara dan data yang digunakan adalah data sekunder.

\section{HASIL \& PEMBAHASAN}

Peta strategi Dinas Pendidikan Kota Surabaya terdiri dari 4 perspektif balanced scorecard, dan masing-masing perspektif terdiri dari satu atau beberapa sasaran strategis (SS) yaitu: Pertama, perspektif keuangan: (a) penggunaan anggaran yang efisien, yaitu tingkat pencapaian realisasi anggaran sesuai dengan target yang telah ditetapkan oleh Dinas Pendidikan Kota Surabaya, dan (b) penggunaan anggaran yang efektif, yaitu tingkat pencapaian tolok ukur kinerja dari setiap kegiatan sesuai dengan target yang telah ditetapkan oleh Dinas Pendidikan Kota Surabaya. Kedua, perspektif pelanggan: (a) kepuasan stakeholder, yaitu representasi dari peningkatan pelayanan yang ada pada Dinas Pendidikan Kota Surabaya terhadap siswa, sekolah, wali murid dan semua yang menjadi stakeholder pendidikan; (b) kepuasan masyarakat, yaitu representasi dari peningkatan pelayanan yang ada pada Dinas Pendidikan Kota Surabaya kepada masyarakat luas baik yang terlibat langsung dalam pendidikan maupun tidak; (c) peningkatan pemerataan pendidikan, yaitu peningkatan akses terhadap lembaga pendidikan sehingga tidak ada lagi anak usia sekolah yang tidak bersekolah, dan (d) peningkatan mutu pendidikan, yaitu peningkatan terhadap output yang dihasilkan dari proses pembelajaran yang telah dilakukan. Ketiga, perspektif proses bisnis internal: (a) peningkatan pemahaman pemberi layanan, yaitu program untuk meningkatkan pemahaman pemberi layanan dalam memberikan layanan pendidikan kepada masyarakat mulai dari warga sekolah dan warga kantor Dinas Pendidikan Kota Surabaya; (b) pengelolaan organisasi, yaitu pengelolaan proses bisnis dan alur pelayanan serta dasar Hukum yang digunakan yang ada di Dinas Pendidikan Kota Surabaya; (c) pemanfaatan teknologi informasi dan komunikasi, yaitu pemanfaatan teknologi informasi dan komunikasi untuk pengolahan data menjadi informasi sebagai sumber atau bahan pengambilan keputusan, dan (d) pengadaan perlengkapan sekolah negeri, yaitu merupakan proses peningkatan pelayanan kepada siswa melalui pemenuhan sarana dan prasarana dari sekolah negeri di bawah naungan Dinas Pendidikan Kota Surabaya. Keempat, perspektif pembelajaran dan pertumbuhan yang meliputi: (a) peningkatan mutu SDM, dan (b) peningkatan mutu SDM adalah program untuk 
meningkatkan kapasitas dan kemampuan dari pendidik, tenaga kependidikan dan peserta didik.

Penyerapan Anggaran dan prosentase ketercapaian tolok ukur kinerja kegiatan, yang pada tahun 2014 untuk Realisasi Penyerapan Anggaran belum dapat melampaui target dari APBD yang telah dianggarkan sehingga capaian kinerjanya sebesar $85,70 \%$ dari target yang telah ditetapkan dan status IKU kuning. Sedangkan untuk prosentase ketercapaian tolok ukur kinerja kegiatan hanya tercapai 20 kegiatan dari total 32 kegiatan sehingga prosentase prosentase ketercapaian tolok ukur kinerja kegiatan sebesar $62,5 \%$ atau status IKU Merah. Perspektif keuangan memiliki dua sasaran strategis (SS) yaitu anggaran yang efisien dan Anggaran yang efektif, dimana SS tersebut belum dapat tercapai untuk anggaran yang efisien dengan nilai skor $85,7 \%$ (status SS kuning) dan untuk anggaran yang efektif dengan nilai skor $62,5 \%$ (status SS merah). Perspektif pelanggan. Pada perspektif pelanggan memiliki 21 IKU meliputi: (1) jumlah pengaduan stakeholder; (2) indeks kepuasan masyarakat; (3) Angka Partisipasi Murni (APM) jenjang PAUD; (4) Angka Partisipasi Murni (APM) Jenjang SD/MI; (5) Angka Partisipasi Murni (APM) Jenjang SMP/MTs; (6) Angka Partisipasi Murni (APM) Jenjang SMA/MA/SMK; (7) Angka Partisipasi Kasar (APK) Jenjang PAUD; (8) Angka Partisipasi Kasar (APK) Jenjang SD/ MI; (9) Angka Partisipasi Kasar (APK) Jenjang SMP/MTs; (10) Angka Partisipasi Kasar (APK) Jenjang SMA/MA/SMK; (11) Angka Melanjutkan SD/MI ke jenjang SMP/MTs; (12) Angka Melanjutkan SMP/MTs ke jenjang SMA/MA; (13)Angka Melek Huruf; (14) Angka Putus Sekolah Jenjang SD/MI; (15) Angka Putus Sekolah Jenjang SMP/MTs; (16) Angka Putus Sekolah Jenjang SMA/MA; (17) Angka Putus Sekolah Jenjang SMK; (18) Angka Kelulusan Jenjang SD/MI; (19) Angka Kelulusan Jenjang SMP/MTS (20) Angka Kelulusan Jenjang SMA/MA, dan (21) Angka Kelulusan Jenjang SMK. Dari 21 IKU ada 20 IKU telah mencapai target (status hijau), namun ada satu IKU yang belum tercapai yaitu Angka Partisipasi Kasar (APK) jenjang SMP/MTS hanya tercapai 95,59\% (status kuning). Berdasarkan hasil tersebut didapatkan kesimpulan bahwa lembaga pendidikan jenjang SMP/ MTS masih kurang dibandingkan dengan jumlah penduduk usia sekolah tersebut.

Untuk Dinas Pendidikan Kota Surabaya ditetapkan bobot tiap perspektif adalah sebagai berikut: (1) perspektif keuangan sebesar 20\%; (2) perspektif pelanggan sebesar $40 \%$; (3) perspektif proses bisnis internal sebesar 20\%, dan (4) perspektif pembelajaran dan 
pertumbuhan 20\%. Pertimbangan penentuan bobot perspektif balanced scorecard di atas adalah sebagai berikut: (1) bobot perspektif pelanggan paling besar $40 \%$ karena Dinas Pendidikan Kota Surabaya adalah dinas teknis yang kebijakannya akan berdampak langsung terhadap masyarakat.

Hasil pengukuran Nilai Kinerja Perspektif (NKP) pada Dinas Pendidikan Kota Surabaya adalah sebagai berikut: Pertama, perspektif Keuangan. Sebagaimana terlihat pada tabel 3, status NKP keuangan berwarna kuning menunjukan kinerja Dinas Pendidikan Kota Surabaya dalam mencapai realisasi anggaran yang telah ditetapkan masih belum cukup baik, masih adanya beberapa kendala di lapangan yang pada akhirnya menghambat proses pelaksanaan sebuah kegiatan dan juga adanya perbedaan antara harga perencanaan dengan harga di lapangan yang mengakibatkan adanya sisa yang tidak bisa lagi untuk direalisasikan dan hal ini mengangu capaian strategi ketersediaan layanan pendidikan yang terlihat dari IKU Angka Partisipasi Kasar (APK) Jenjang SMP/MTs yang masih status berwarna kuning karena belum mencapai standar.

\section{SIMPULAN \& SARAN}

Berdasarkan analisis pencapaian strategi menggunakan balanced scorecard pada strategi yang digunakan oleh Dinas Pendidikan Kota Surabaya dalam meningkatkan mutu pendidikan di Kota Surabaya tahun 2015 telah tercapai dengan baik hal ini ditunjukan dengan capaian NKU sebesar 102,31\% yang berarti telah memenuhi target yang telah ditetapkan 100\%. Namun demikian status NKP keuangan berwarna kuning menunjukan kinerja Dinas Pendidikan Kota Surabaya dalam mencapai realisasi anggaran yang telah ditetapkan masih belum cukup baik, masih adanya beberapa kendala di lapangan yang pada akhirnya menghambat proses pelaksanaan sebuah kegiatan dan juga adanya perbedaan antara harga perencanaan dengan harga di lapan gan yang mengakibatkan adanya sisa yang tidak bisa lagi untuk direalisasikan.

Selanjutnya, Dinas Pendidikan Kota Surabaya perlu untuk memaksimalkan proses perencanaan anggaran sehingga anggaran yang telah ditetapkan akan dapat lebih efektif dan efisien. Termasuk dalam hal ini adalah perlu adanya evaluasi rutin terhadap pelaksanaan kegiatan yang ada di Dinas Pendidikan Kota Surabaya dalam rangka meningkatkan prosentase realisasi anggaran. Untuk penelitian selanjutnya bisa dilakukan penelitian 
pengaruh dari masingmasing perspektif terhadap capaian kinerja dengan memasukan unsur lingkungan eksternal

\section{DAFTAR PUSTAKA}

Alimudin, A. (2017). Analisis Pencapaian Strategi Menggunakan Balanced Scorecard. Jurnal Pendidikan Ekonomi \& Bisnis, 5 (2) 2017, 194-205 